trative divisions of that governorship, and on the important problem of semi-nomad tribes, with their subdivisions and ruling families (reports of 1903-6). In 1906 he was transferred to the consular service and posted to Rasht where he spent six years, devoting his leisure to the study of the geography, history, inscriptions and industries of the Caspian provinces. Till the last days of his life he remained faithful to this early attachment. Expressing himself with equal facility in English and in French, he wrote a great number of books, articles, and reports on his travel impressions and on the geography and history of the southern coast of the Caspian.

In 1912 Rabino was appointed to Mogador (Morocco) where he became interested in the legal organization of the hubus (waqf "pious foundations"). After serving in Smyrna and Salonika he finished his career as Consul-General in Cairo (1929-37), but till 1947 the Foreign Office often took advantage of his experience.

L. H. Rabino had the excellent idea of inserting his own bibliography at the end of his book called Coins, Medals, and Seals of the Shähs of Iran (1509-1941), published by the Persian Government (London, 1945). After that he produced several other works, the last the very useful " Coins of the Jalā'ir, Kara koyunlu, Musha'sha" and Ak koyunlu dynasties" (which appeared posthumously in the Numismatic Chronicle, sixth series, vol. $\mathrm{x}, 1950$ ).

The best-known books by H. L. Rabino are "Les provinces caspiennes de la Perse. Le Guîlân", Revue du Monde Musulman, vol. xxxvii, 1916, and "Mazandaran and Astarabad", in the E. J. W. Gibb Memorial series, 1928. They will long remain sources of information, as also will his studies in the complicated genealogies of the rulers of the Caspian provinces (in JRAS. and the Journal Asiatique), and his last two numismatic surveys of Persian dynasties. It is a gratifying thought that amid multifarious official duties and despite indifferent health, H. L. Rabino could carry on his favourite studies with so much energy and perseverance.

V. MiNORSKY.

\title{
R. E. Enthoven
}

Mr. Reginald Edward Enthoven, C.I.E., who entered the Indian Civil Service in Bombay in the same year as Sir Charles Fawcett, died soon after him, on 21st May, 1952, being also in his eightythird year. Educated at Wellington and New College, Oxford, he 
joined the Indian Civil Service in 1887. Throughout his service he had taken much interest in the people of the Bombay Presidency, especially in their customs and traditions, and in anthropological matters generally. The knowledge thus acquired was embodied in two standard works, Tribes and Castes of Bombay and The Folklore of Bombay. Retiring in 1920 as Commissioner of Customs, Salt, and Excise, Bombay, Enthoven settled in England, and served most usefully for many years on the Council of the Society.

P. R. CADELL.

\section{Sir Charles G. H. Fawcett}

Sir Charles Gordon Hill Fawcett died in March, 1952, in his eighty-third year. Born in 1869 he was educated at Harrow and Pembroke College, Cambridge, and entered the Indian Civil Service in 1890 , being posted to Bombay, where he served for many years, becoming a Judge of the High Court. He had shown his interest in the early years of the British connection with India by contributions to the Journal of the Bombay Branch of the Royal Asiatic Society and, after his retirement, he combined this interest with his judicial knowledge in the production of his book The First Century of British Justice in India. He also edited the first volumes of the new series of English Factories in India, and for the Hakluyt Society the Travels of Abbé Carré, which were translated by his wife from the original French manuscript. He also edited Sir Evan Cotton's unfinished East Indiamen, an account of the East India Company's maritime service. All his work was marked by extreme care and accuracy.

\section{P. R. CADELL.}

\section{Ernest Herbert Cooper Walsh}

Ernest Herbert Cooper Walsh, C.S.I., whose death has occurred at the age of 87, was from 1907 a member of this Society. In India he was (1901-1919) a member of the Asiatic Society of Bengal ; in the Bihar and Orissa Research Society he served as Vice-President (1917-18), President (1919), and Secretary for Archæology and Numismatics, and on retirement was elected an Honorary Member. After returning to England (1920) he was Lecturer in Tibetan at the London School of Oriental Studies (1920) and Lecturer in Bengali 